\title{
MODERN APPROACHES TO STUDYING THE ISLAMIC TAXATION IN THE RUSSIAN MARKET OF MUSLIM GOODS
}

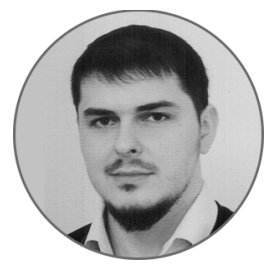

Article history:

Received 13 February 2017

Received in revised form 3 March 2017

Accepted 17 March 2017

Translated 1 September 2017

Available online 15 September 2017

JEL classification: B52, H29, Z12

Keywords: Zakat, Islamic taxes, market

of Muslim goods, Islamic finance

\section{Shamil'A. SHOVKHALOV}

Siberian Federal University, Krasnoyarsk, Russian Federation

shovkhalov.shamil@gmail.com

The editor-in-charge of this article was Irina M. Komarova

Authorized translation by Irina M. Komarova

Contemporary economists, more often than not, tend to explore possible methods for eliminating the social inequality. In this respect, economic growth becomes the issue of secondary importance. According to statistics, some advanced economies have seen the 60-percent growth in the wealthiest population (1 percent) for the recent one hundred years. Seven largest and advanced economies and seven emerging economies have the Gini index of 0.71 and 0.8 respectively [1]. O.S. Sukharev, a Russian scholar, suggests creating support system for the poor population, as an initial solution, so to improve its welfare. However, the poor population's income should outperform that of the wealthy population, since

\footnotetext{
${ }^{\dagger}$ For the source article, please refer to: Шовхалов Ш.А. Современные подходы к исследованию исламского налогообложения на отечественном рынке мусульманских товаров. Финансы и кредит. 2017. Т. 23. Вып. 19. С. 1144-1152. URL: https://doi.org/10/24891/fc.23.19.1144
}

the perceptions of poverty are difficult to neglect in comparison with the highest income level ${ }^{1}$.

According to some economists, the poor population support systems may be implemented through Zakat, one of the fundamental principles in Islam. Zakat is an obligatory contribution to certain social layers individuals must make when they reach a stipulated level of wealth (Nisab). This problem grows even more important as the market of Muslim goods ${ }^{2}$ [2] and Islamic finance expands in Russia [3-5].

\footnotetext{
${ }^{1}$ Sukharev O.S. [Methodological principles of institutional analysis: The old and new schools and mainstream]. Finansovaya analitika: problemy i resheniya = Financial Analytics: Science and Experience, 2013, no. 41, pp. 7-24. (In Russ.)

${ }^{2}$ Shovkhalov Sh.A., Petrova A.T. [The market of Muslim goods: Essence and Features]. Fundamental'nye issledovaniya = Fundamental Research, 2015, no. 6-1, pp. 207-210. (In Russ.)
} 
The Islamic law sets forth about six principles governing the origination of the Zakat obligation. In this research, I focus on the most relevant to the Russian market.

\section{A person should be a Muslim.}

People, other than Muslims, are not subject to Zakat. This clause is applicable in case of a joint venture (a joint-stock company, limited liability company, etc.). Assessing the amount of Zakat, entities should take the property owned by a Muslim as the taxable base (stocks, shares in the authorized capital, etc.).

2. A person shall possess a certain amount of Nisab for over one lunary year (354/355 days).

$N i s a b$ is the value or quantity of the property that entails Zakat in case of its growth. According to the Shafi'i madhhab (school of law), the first date of profit-making operations is taken to assess Zakat, notwithstanding whether the property meets the Nisab criteria or not as at the given moment. For example, a sole proprietor assumes its business operations on January 1. He had five pairs of shoes to sell for RUB 10,000, i.e. below the Nisab level. However, if the property reaches the Nisab level in 354 days, starting from January 1, the sole proprietor must pay 2.5 percent on the value of all the goods. If an individual possesses 40 grams of gold as of January 1, but the gold possessions reach 85 gram only on June 1 , that is, it exceeds Nisab, the individual is to pay 2.5 percent on 85 grams of gold in 354 days, starting from June 1, rather than January 1 (2.125 grams in monetary terms).

3. The property shall be obtained in the Shariah-permitted manner.

A legal entity accrues the income item Interests Receivable. This amount is not subject to Zakat, but shall be distributed to the poor population [6].

Thus, settling the key concepts of this subject area, I analyze proceedings by the Russian researches into Islamic taxes. They can be conditionally divided into proceedings by religious personalities [7, 8] and academic researches. The latter become the focal point of this research. These are:

- monograph, An Islamic Economic Model and Modern Times, by R.I. Bekkin (2010) [9];
- paper, Zakat: A Practical Guidance for Calculation, Payment and Distribution of Zakat, by M.E. Kalimullina, R.I. Bekkin (2009) [10];

- paper, Calculation of Zakat in Russia Based on Balance Sheet, by G.Kh. Koveshnikova, Sh.M. Abubekerov (2008) [11];

- handbook, Taxes and Taxation in Islamic Economies, by I.Yu. Zobova (2008) ${ }^{3}$.

It is noticeable that all the above papers were published within 2008 through 2010. I should also spotlight such authors as R.Yu. Pochekaev [12], N.A. L'vova and N.V. Pokrovskaya ${ }^{4}$.

In his monograph, An Islamic Economic Model and Modern Times, R.I. Bekkin scrutinizes the way Zakat is implemented, starting from the caliphate time and onward, in Yemen, Saudi Arabia, Pakistan, Libya, Sudan and Malaysia. The monograph was released in 2010 forerun by Bekkin's other proceedings [13-15]. In those proceedings, Bekkin articulated original ideas of Zakat. However, An Islamic Economic Model and Modern Times, represents an amplified and extended overview. I draw upon it in this research. The author reviews the Zakat practice in Russia and points out some issues relative to the subject:

- nonexistent culture of Zakat;

- prevailing public unawareness of Zakat;

- confusion of Zakat and alms;

- nonexistent centralized procedure for charging Zakat.

R.I. Bekkin notes that the collection and distribution of Zakat do not entail any amendments to the effective legislation, being an indisputable merit in comparison with other aspects of the Islamic economy. He also refers to the Republic of Karelia that successfully enforces the Zakat practices. However, he predicts the promising future for various charitable foundations. Despite an apparent excellence of the monograph, R.I. Bekkin fails to address the Zakat assessment method.

\footnotetext{
${ }^{3}$ Zobova I.Yu. Nalogi i nalogooblozhenie v stranakh s Islamskoi ekonomikoi [Taxes and Taxation in Islamic Economies]. Kazan, TGGPU Publ., 2008, 148 p.

${ }^{4}$ L'vova N.A., Pokrovskaya N.V. [Special features of Islamic taxation in the modern financial system]. Finansy $i$ kredit = Finance and Credit, 2015, no. 8, pp. 31-40. (In Russ.)
}

Please cite this article as: Shovkhalov Sh.A. Modern Approaches to Studying the Islamic Taxation in the Russian Market of Muslim Goods. 
In her paper, Taxes and Taxation in Islamic Economies (2008), I.Yu. Zobova, in fact, echoes the main conclusions made by R.I. Bekkin, without offering any new ideas.

The handbook, Zakat: A Practical Guidance (2009), became widespread owing to the renowned authors (M.E. Kallimulina, R.I. Bekkin). The authors approached the issue through the lens of classical proceedings on the Islamic law, i.e. the substance of Zakat as per the Koran and hadiths, its assessment and payment. They also express their ideas on the practical use of Zakat in Russia and some other countries. The first two chapters contain some aspects, which diverge with the Islamic law (Table 1).

The handbook does not provide any comprehensive technique for legal entities to assess Zakat.

In my opinion, the paper, Calculation of Zakat in Russia Based on Balance Sheet (2008), by G.Kh. Koveshnikova and Sh.M. Abubekerov became a real methodological breakthrough. Despite many attainments, I still have to note some discrepancies with the Islamic law (Table 2).

Basically, G.Kh. Koveshnikova and Sh. M. Abubekerov give a detailed view of balance sheet items in Russia collating them with Zakat. However, I highlight the most important aspects of the paper, besides the above ones:

- it lacks the Zakat assessment technique for legal entities, offering just several formulas;
- balance sheet underwent significant modifications after 2011 as accounting practices developed in Russia. Thus, the information got outdated to a certain extent.

A special mention shall be made concerning the article by N.A. L'vova and N.V. Pokrovskaya. Unlike the previous researches, they raise the question of a missing assessment technique, but still give way to some inaccuracies (Table 3).

Notwithstanding apparent omissions, N.A. L'vova and N.V. Pokrovskaya return to the importance of Islamic taxes, stating that respective studies might provide rather valuable findings to subsequently eliminate the economic disparity as mentioned in the opening idea of this research.

Hence, the above proceedings and their scholarly approaches may be classified into historical (for example, proceedings by R.I. Bekkin) and methodological (for example, proceedings by M.E. Kalimullina, G.Kh. Koveshnikov). In my opinion, the first group of proceedings makes rather uncontroversial conclusions, while significant fallacies were traced in the second one (Tables 1, 2 and 3) with respect to the Islamic tax assessment. They fail to present a comprehensive technique for legal entities to assess the tax. This fact shall motivate scholars for further researches, considering a growth in the Muslim population [16] and the market of Muslim goods and Islamic finance $[17,18]$. 
Table 1

Discrepancies between the paper, Zakat: A Practical Guidance, and Islamic law

\begin{tabular}{lll}
\hline Page & Zakat: A Practical Guidance & Islamic law \\
\hline 62 & An individual must pay Zakat on the leased-out property & $\begin{array}{l}\text { Zakat is not charged on the leased-out property, but Zakat applies } \\
\text { to rental payments }\end{array}$ \\
\hline 62 & $\begin{array}{l}\text { As pronounced by the Shafi'i school of law, rental payments } \\
\text { are not subject to Zakat }\end{array}$ & $\begin{array}{l}\text { According to the Shafi'i school of law, rental payments are subject } \\
\text { to Zakat }\end{array}$ \\
\hline 63 & $\begin{array}{l}\text { In selling a farm, Zakat shall be paid on cereal crops, 5 percent } \\
\text { or } 10 \text { percent }\end{array}$ & In selling cereal crops, the Zakat rate is 2.5 percent \\
\hline 63 & If land is privately used, Zakat is not charged & $\begin{array}{l}\text { According to the Shafi'i school of law, Zakat arises when crops } \\
\text { exceed 653 kg }\end{array}$ \\
\hline 63 & Horses are subject to 2.5 percent Zakat & $\begin{array}{l}\text { In selling horses, Zakat rate is 2.5 percent. In breeding horses, } \\
\text { Zakat is not charged, according to the Shafi'i school of law }\end{array}$ \\
\hline 64 & $\begin{array}{l}\text { 100 percent Zakat is charged on interests gained, prohibited } \\
\text { pool of funds, bonds held for sale and dividends from } \\
\text { prohibited business activities }\end{array}$ & $\begin{array}{l}\text { Zakat is not charged on such items, but income shall be } \\
\text { distributed to social needs }\end{array}$ \\
\hline 64 & Excess private property is subject to Zakat & Private property is not subject to Zakat, unless it is offered for sale \\
\hline 65 & Zakat is charged on expensive work of art and jewelry & Zakat is not charged on such items, unless they are sold \\
\hline 71 & If an individual does not possess any residential property, & $\begin{array}{l}\text { If the property of an individual reaches the level of Nisab, it is } \\
\text { subject to Zakat, notwithstanding the availability of a residential } \\
\text { property }\end{array}$ \\
\hline
\end{tabular}

Source: Authoring

Table 2

Discrepancies between the paper, Calculation of Zakat in Russia Based on Balance Sheet, and Islamic law

\begin{tabular}{lll}
\hline Page & $\begin{array}{l}\text { Calculation of Zakat in Russia Based on } \\
\text { Balance Sheet }\end{array}$ & Islamic law \\
\hline 24 & $\begin{array}{l}\text { The authors attribute activities for } \\
\text { dissemination of knowledge and profitable } \\
\text { projects to the concept of expenses in the way } \\
\text { of Allah }\end{array}$ & $\begin{array}{l}\text { Publication of books, construction of schools, projects, etc. may not be financed } \\
\text { with Zakat contributions, according to the majority of law experts }\end{array}$ \\
\hline $33,89,90$ & Honey is subject to 10-percent Zakat rate & $\begin{array}{l}\text { According to four schools of law, Zakat is not charged on honey, unless honey is } \\
\text { sold. According to the Hanafi and Hanbali madhhabs, Zakat is paid when honey } \\
\text { proceeds from territories within the ushr* jurisdictions, but it is irrelevant to } \\
\text { Russia }\end{array}$ \\
\hline 33 & $\begin{array}{l}\text { It is true from religious perspectives, but it is methodologically preferable to pay } \\
\text { Zakat is advisable to pay in Ramadan }\end{array}$ & $\begin{array}{l}\text { Zakat in the end of a lunary year, starting from the moment a person arrives at } \\
\text { Nisab or starts business activities. It mitigates assessment errors }\end{array}$ \\
\hline 34 & $\begin{array}{l}\text { A lunary year is determined for each item of property (gold, grains, unless they are } \\
\text { goods of the same entity). According to some papers, experts in the Islamic law } \\
\text { property subject to Zakat, even if the timing } \\
\text { parameter differs }\end{array}$ & \begin{tabular}{l} 
unanimously agree with it* \\
\hline
\end{tabular}
\end{tabular}

Note. ${ }^{*}$ Tarmakhomed S. Sushchestvuet li nisab v otnoshenii meda? [Is any Nisab level established for honey?]. URL: http://askimam.ru/fatwa/zakyat-isadaka/sushchestvuet-li-nisab-v-otnoshenii-meda (In Russ.)

** Vakhitov M. Nekotorye voprosy po zakyatu [Some aspect of Zakat]. URL: http://islameconomy.ru/articles/stati-po-fikkhu/nekotorye_voprosy_po_zakyatu_3 (In Russ.)

Source:Authoring

Please cite this article as: Shovkhalov Sh.A. Modern Approaches to Studying the Islamic Taxation in the Russian Market of Muslim Goods. 
Table 3

Discrepancies between the paper, Specifics of Islamic Taxes under Modern Financial System, and Islamic law

\begin{tabular}{|c|c|c|}
\hline Page & $\begin{array}{l}\text { Specifics of Islamic Taxes under Modern Financial } \\
\text { System }\end{array}$ & Islamic law \\
\hline 34 & The value of leased-out real estate is subject to Zakat & $\begin{array}{l}\text { Zakat is not charged on the leased-out property, but it applies to } \\
\text { rental payment from such property }\end{array}$ \\
\hline 34 & $\begin{array}{l}\text { Zakat is charged on the value of available horses, motor } \\
\text { vehicles, other than for constant use }\end{array}$ & Zakat is charged on such assets only if they are sold \\
\hline 34 & Bank interests are subject to Zakat & $\begin{array}{l}\text { Zakat is not charged on interests at all, but this income shall be } \\
\text { contributed to social needs }\end{array}$ \\
\hline 34 & The value of other jewelry is subject to Zakat & Gemstones, metals, other than gold and silver, are not subject to Zakat \\
\hline 38 & The taxable income was very difficult to determine & $\begin{array}{l}\text { Books on Islamic law provide affluent examples and rules for Zakat } \\
\text { assessment. Difficulties were certainly possible when new economic } \\
\text { realities appeared, but the issues were address as they arose }\end{array}$ \\
\hline
\end{tabular}

Source: Authoring

\section{References}

1. Mel'yantsev V.A. [Global economy slowdown and (semi)peripheral countries]. Aziya i Afrika segodnya = Asia and Africa Today, 2016, no. 10, pp. 27-34. (In Russ.)

2. Shovkhalov Sh.A., Petrova A.T. [Influence of the religious factor on economic behavior of market participants]. Vestnik Altaiskoi nauki = Altai Science Bulletin, 2015, no. 3-4, pp. 585-589. (In Russ.)

3. Zhuravlev A.Yu. [Islamic finance and its teaching as an academic discipline]. Finansovyi biznes = Financial Business, 2013, no. 6, pp. 57-60. (In Russ.)

4. Musaev R.A., Magomedova Yu.D. [Islamic financial institutions in the world economy]. Vestnik Moskovskogo universiteta. Seriya 6: Ekonomika = Moscow University Economics Bulletin, 2013, no. 2, pp. 18-28. (In Russ.)

5. Musaev R.A., Magomedova Yu.D. [Trends in Islamic financial institutions development under globalization]. Problemy teorii i praktiki upravleniya = Theoretical and Practical Aspects of Management, 2015, no. 11, pp. 39-48. (In Russ.)

6. Shovkhalov Sh.A. Otsenka deyatel'nosti predpriyatii rynka musul'manskikh tovarov: monografiya [Assessing the activity of enterprises in the market of Muslim goods: a monograph]. Krasnoyarsk, Siberian Federal University Publ., 2016, 140 p.

7. Bigiev M. Zakyat [Zakat]. Naberezhnye Chelny, Islam Nury Publ., 2013, 228 p.

8. Shentyurk M.Kh. Zakyat. Vera i praktika [Zakat. Faith and practice]. Moscow, Novyi svet Publ., 2008,222 p.

9. Bekkin R.I. Islamskaya ekonomicheskaya model' i sovremennost' [An Islamic economic model and modern times]. Moscow, Mardzhani Publ., 2010, 352 p.

10. Kalimullina M.E., Bekkin R.I. Zakyat: prakticheskoe rukovodstvo: posobie po raschetu, vyplate i raspredeleniyu zakyata [Zakat: A practical guidance for calculation, payment and distribution of zakat]. Moscow, Islamskaya kniga Publ., 2009, 160 p.

11. Koveshnikova G.Kh., Abubekerov Sh.M. Raschet zakyata v Rossii po bukhgalterskomu balansu [Calculation of Zakat in Russia Based on Balance Sheet]. Moscow, Izdatel'skii otdel Soveta muftiev Rossii Publ., 2008, 105 p.

12. Pochekaev R.Yu. [Islam, taxes and the empire: Tax institution of zakat in Bukhara and Khiva during the Russian protectorate era]. Strany i narody Vostoka = Countries and Peoples of the East, 2015, no. 26, pp. 97-112. (In Russ.) 
13. Bekkin R.I. Islamskaya ekonomika. Kratkii kurs [Islamic economy: A short course]. Moscow, AST, Vostok-Zapad Publ., 2008, 288 p.

14. Bekkin R.I. [Zakat: A tax or religious duty?]. Finansy = Finance, 2008, no. 11, pp. 35-39. (In Russ.)

15. Bekkin R.I. Islamskie finansy v sovremennom mire: ekonomicheskie i pravovye aspekty [Islamic finance in the modern world: Economic and legal aspects]. Moscow, Umma Publ., 2004, 283 p.

16. Christiansen B., Yıldız S., Yıldız E. Handbook of Research on Effective Marketing in Contemporary Globalism. USA, IGI Global, 2014, 463 p.

17. Petrova A.T., Shovkhalov Sh.A. Growth Prospects for Market of Muslim goods in Russia. Indian Journal of Science and Technology, 2016, vol. 9, iss. 46, pp. 435-441. URL: https://doi.org/10.17485/ijst/2016/v9i46/107512

18. Varinli I., Yildiz E. A Study for Determining the Effects on the Perceptions of Consumers about Halal Food. Cairo, 2012, $63 \mathrm{p}$.

\section{Conflict-of-interest notification}

I, the author of this article, bindingly and explicitly declare of the partial and total lack of actual or potential conflict of interest with any other third party whatsoever, which may arise as a result of the publication of this article. This statement relates to the study, data collection and interpretation, writing and preparation of the article, and the decision to submit the manuscript for publication. 